\title{
Numerical Taxonomic Analysis on Some Lepidium L. taxa (Brassicaceae) from Turkey
}

\author{
Mehmet Bona' \\ 'Istanbul University, Science Faculty, Department of Biology, Division of Botany, Istanbul, Turkey
}

ORCID IDs of the authors: M.B. 0000-0003-1656-2641

Please cite this article as: Bona M. Numerical Taxonomic Analysis on Some Lepidium L. taxa (Brassicaceae) from Turkey. Eur J Biol 2020; 79(2): 132-143. DOI: 10.26650/EurJBiol.2020.0020

\begin{abstract}
Objective: This study reveals the relationship between Lepidium campestre, L. spinosum, L. sativum ssp. sativum, L. sativum ssp. spinescens, L. ruderale, L. virginicum, L. perfoliatum, L. vesicarium, L. caespitosum, L. pumilum, L. cartilagineum, L. latifolium, L. lyratum, L. graminifolium, to determine the effectiveness of the characters used in taxonomic classification, and to help solve taxonomical problems of this large genus at the specific and intraspecific levels by comparing the numerical results with classical taxonomic classification.
\end{abstract}

Materials and Methods: This numerical taxonomic study is based on morphological data that come from a wide range of herbarium material and material collected in the wild. For the analyses, 14 taxa were studied. A range of characteristics of sepal, petal, stamen, silicle, pedicel, septum, stigma, and sinus that are considered to be taxonomically important in the genus were investigated. Morphological data, 90 character states, which belong to 55 characters scored as the binary state for each taxon were used in unweighted pair-group method using arithmetic averages and principle components analyses.

Results: L. caespitosum, L. pumilum and L. cartilagineum are recognised at species rank, not subspecies or varieties. L. sativum ssp. sativum and L. sativum ssp. spinescens should be evaluated as two subspecies not synonyms of Lepidium sativum. The most effective characters for the delimitation of the studied taxa are seed length, the habitus of plant, sepal length, septum length, seed wings, the presence of swelling leaf residues on the base of the plant, pedicel length.

Conclusion: Numerical analysis studies based on morphological data on Lepidium taxa growing in Turkey are a useful tool for solving the taxonomic problems of taxa belonging to the genus Lepidium.

Keywords: Brassicaceae, Lepidium, Numerical Taxonomy, PCA, UPGMA

\section{INTRODUCTION}

The Brassicaceae is one of the largest families that has major scientific and economic importance $(1,2)$. There are 3660 species and 321 genera in 49 tribes in the family (3). The classification of the Brassicaceae is problematic because the characters traditionally used are variable, even within genera, and may not support natural groups (4).

The first comprehensive taxonomic approach of the Brassicaceae is based on two characteristics: the position of the radicle with cotyledons in the seed and fruit type (5). After almost a century, tribal and subtribal classification revised mainly based on fruit characters and seed morphology (6). Brassicaceae is represented by 555 species and 91 genera in the Flora of Turkey (6-9). Generic delimitation has been changed according to molecular phylogenetic studies focused on Brassicaceae in the last two decades (10-12). Recent studies show that Turkey is a centre of diversity with 660 taxa belonging to 91 genera, including 571 species, 65 subspecies, and 24 varieties (13).

The genus Lepidium L. is primarily distributed in temperate and subtropical regions (14). The genus includes 250 species and one of the largest genera in the Brassicaceae (3). Cardaria Desv. was defined as 
a section of Lepidium (15), later it was accepted as a separate genus $(7,14,16)$. In light of molecular research not only Cardaria but also Coronopus, Stroganowia, Winklera Regel, and Stubendorffia Schrenk ex Fisch., C.A. Mey. \& Avé-Lall. have been classified within Lepidium sensu lato $(10,12,17-20)$.

Cardaria, Coronopus, and Stroganowia are represented by five species in Turkey: L. coronopus (L.) Al-Shehbaz and L. didymium L. (formerly Coronopus), L. draba L. and L. chalepense L. (formerly Cardaria), Stroganowia leventii V.I. Dorofeev $(3,21-23)$

Lepidium sensu stricto (excluding Cardaria, Coronopus, and Strogonovia) includes 13 species and 2 subspecies in Turkey $(7,8,24)$.

Numerical taxonomy is a grouping method that groups to a taxonomic unit based on their character states using statistical methods (25). In this study, the morphological features of Lepidium s.str. taxa distributed in Turkey were examined and their diagnostic characteristics were determined. Detailed measurements based on these characters were used in numerical taxonomic analyses.

This study reveals the relationship between $L$. campestre, $L$. spinosum, L. sativum ssp. sativum, L. sativum ssp. spinescens, L. ruderale, $L$. virginicum, $L$. perfoliatum, $L$. vesicarium, $L$. caespitosum, L. pumilum, L. cartilagineum, L. latifolium, L. lyratum, L. graminifolium, to determine the effectiveness of the characters used in taxonomic classification, and to help solve taxonomical problems of this large genus at specific and intraspecific ranks by comparing the numerical results with classical taxonomic classification.

\section{MATERIALS AND METHODS}

The flowering and fruiting material of the genus Lepidium were collected from different parts of Turkey during the period May-August 2008, 2009 and 2010. Specimens were collected from as many different parts of the distribution area of the genus as possible in order to thoroughly examine variation patterns. The specimens collected were kept at the Istanbul Uni- versity, Department of Pharmaceutical Botany Herbarium (ISTE) and compared with the collections of ANK, E, GAZI, HUB, ISTF, ISTE, $\mathrm{K}$, and VAN herbaria.

A range of characteristics of sepal, petal, stamen, silicle, pedicel, septum, stigma, and sinus that are considered to be taxonomically important in the genus were investigated. For these investigations, all parts of the specimens were photographed using MOTIC 2000 camera stereo microscope system, and then measured by using Motic Image Plus 2.0-program. These measurements were used for numerical analyses. For the analyses, 14 taxa (Table 1) and 90 character states, which belong to 55 characters, were scored as the binary state for each taxon (Table 2). To investigate the relationships between the studied taxa,

Table 1. Studied taxa list.

\begin{tabular}{ll}
\hline OTU1 & L. campestre \\
\hline OTU2 & L. spinosum \\
\hline OTU3 & L. sativum ssp. sativum \\
\hline OTU4 & L. sativum ssp. spinescens \\
\hline OTU5 & L. ruderale \\
\hline OTU6 & L. virginicum \\
\hline OTU7 & L. perfoliatum \\
\hline OTU8 & L. vesicarium \\
\hline OTU9 & L. caespitosum \\
\hline OTU10 & L. pumilum \\
\hline OTU11 & L. cartilagineum \\
\hline OTU12 & L. latifolium \\
\hline OTU13 & L. lyratum \\
\hline OTU14 & L. graminifolium \\
\hline
\end{tabular}

Table 2. Character list.

\begin{tabular}{lll}
\hline No & Characters & Character states \\
\hline C1 & Fruit length maximum value & Shorter or longer than $3 \mathrm{~mm}$ \\
\hline C2 & & Shorter or longer than $4 \mathrm{~mm}$ \\
\hline C3 & Fruit length minimum value & Shorter or longer than $5 \mathrm{~mm}$ \\
\hline C4 & & Shorter or longer than $2 \mathrm{~mm}$ \\
\hline C5 & Fruit width maximum value & Shorter or longer than $3 \mathrm{~mm}$ \\
\hline C6 & & Shorter or longer than $4 \mathrm{~mm}$ \\
\hline C7 & & Shorter or longer than $3 \mathrm{~mm}$ \\
\hline C8 & & Shorter or longer than $4 \mathrm{~mm}$ \\
\hline
\end{tabular}


Table 2. Continue

\begin{tabular}{|c|c|c|}
\hline C9 & Fruit width minimum value & Shorter or longer than $2 \mathrm{~mm}$ \\
\hline C10 & & Shorter or longer than $3 \mathrm{~mm}$ \\
\hline C11 & Pedicel length maximum value & Shorter or longer than $4 \mathrm{~mm}$ \\
\hline $\mathrm{C} 12$ & & Shorter or longer than $6 \mathrm{~mm}$ \\
\hline C13 & Pedicel length minimum value & Shorter or longer than $2 \mathrm{~mm}$ \\
\hline C14 & & Shorter or longer than $3 \mathrm{~mm}$ \\
\hline C15 & Septum length maximum value & Shorter or longer than $2.5 \mathrm{~mm}$ \\
\hline C16 & & Shorter or longer than $3.5 \mathrm{~mm}$ \\
\hline $\mathrm{C} 17$ & Septum length minimum value & Shorter or longer than $2 \mathrm{~mm}$ \\
\hline C18 & & Shorter or longer than $3 \mathrm{~mm}$ \\
\hline C19 & Septum width maximum value & Shorter or longer than $0.7 \mathrm{~mm}$ \\
\hline $\mathrm{C} 20$ & Septum width minimum value & Shorter or longer than $0.5 \mathrm{~mm}$ \\
\hline $\mathrm{C} 21$ & Stigma length maximum value & Shorter or longer than $0.3 \mathrm{~mm}$ \\
\hline $\mathrm{C} 22$ & & Shorter or longer than $0.5 \mathrm{~mm}$ \\
\hline $\mathrm{C} 23$ & Stigma length minimum value & Shorter or longer than $0.25 \mathrm{~mm}$ \\
\hline $\mathrm{C} 24$ & Stigma width maximum value & Shorter or longer than $0.25 \mathrm{~mm}$ \\
\hline $\mathrm{C} 25$ & & Shorter or longer than $0.35 \mathrm{~mm}$ \\
\hline $\mathrm{C} 26$ & Stigma width minimum value & Shorter or longer than $0.15 \mathrm{~mm}$ \\
\hline $\mathrm{C} 27$ & & Shorter or longer than $0.25 \mathrm{~mm}$ \\
\hline $\mathrm{C} 28$ & Sepal length maximum value & Shorter or longer than $1.5 \mathrm{~mm}$ \\
\hline $\mathrm{C} 29$ & Sepal length minimum value & Shorter or longer than $1 \mathrm{~mm}$ \\
\hline $\mathrm{C} 30$ & Sepal width maximum value & Shorter or longer than $1 \mathrm{~mm}$ \\
\hline C31 & Sepal width minimum value & Shorter or longer than $0.8 \mathrm{~mm}$ \\
\hline $\mathrm{C} 32$ & Petal length maximum value & Shorter or longer than $2.5 \mathrm{~mm}$ \\
\hline C33 & Petal length minimum value & Shorter or longer than $2 \mathrm{~mm}$ \\
\hline C34 & Petal width maximum value & Shorter or longer than $1 \mathrm{~mm}$ \\
\hline C35 & & Shorter or longer than $1.6 \mathrm{~mm}$ \\
\hline C36 & Petal width minimum value & Shorter or longer than $0.8 \mathrm{~mm}$ \\
\hline C37 & Stamen length maximum value & Shorter or longer than $2 \mathrm{~mm}$ \\
\hline C38 & Stamen length minimum value & Shorter or longer than $1.5 \mathrm{~mm}$ \\
\hline C39 & Seed length maximum value & Shorter or longer than $2 \mathrm{~mm}$ \\
\hline $\mathrm{C} 40$ & & Shorter or longer than $2.5 \mathrm{~mm}$ \\
\hline C41 & Seed length minimum value & Shorter or longer than $1.5 \mathrm{~mm}$ \\
\hline $\mathrm{C} 42$ & & Shorter or longer than $2 \mathrm{~mm}$ \\
\hline $\mathrm{C} 43$ & Seed width maximum value & Shorter or longer than $1 \mathrm{~mm}$ \\
\hline
\end{tabular}


Table 2. Continue

\begin{tabular}{|c|c|c|}
\hline $\mathrm{C} 44$ & Seed width minimum value & Shorter or longer than $1 \mathrm{~mm}$ \\
\hline $\mathrm{C} 45$ & Basal leaves length minimum value & Shorter or longer than $15 \mathrm{~cm}$ \\
\hline $\mathrm{C} 46$ & Basal leaves width minimum value & Shorter or longer than $4 \mathrm{~cm}$ \\
\hline $\mathrm{C} 47$ & Basal leaves pedicel length minimum value & Shorter or longer than $4 \mathrm{~cm}$ \\
\hline C48 & Plant length maximum value & Shorter or longer than $50 \mathrm{~cm}$ \\
\hline C49 & Life time & Perennial or not \\
\hline C50 & Habitus & Erect or not \\
\hline C51 & & Single stemmed or not \\
\hline C52 & & Many stemmed or not \\
\hline $\mathrm{C} 53$ & Plant surface & Basal part naked or not \\
\hline C54 & & Upper part naked or not \\
\hline C55 & & Plant waxy or not \\
\hline C56 & Swelling nodes existence & Present or absent \\
\hline C57 & Petiola remains existence & Present or absent \\
\hline C58 & Basal leaves shape & Lyrate basal leaves present or absent \\
\hline C59 & & Pinnatisect basal leaves present or absent \\
\hline $\mathrm{C} 60$ & & 2-pinnatisect basal leaves present or absent \\
\hline C61 & & 3-pinnatisect basal leaves present or absent \\
\hline C62 & & Lanceolate basal leaves present or absent \\
\hline C63 & & Ovate basal leaves present or absent \\
\hline C64 & & Linear basal leaves present or absent \\
\hline C65 & & Lanceolate basal leaves present or absent \\
\hline C66 & Cauline leaves shape & Pinnatisect cauline leaves present or absent \\
\hline C67 & & 2-pinnatisect cauline leaves present or absent \\
\hline C68 & & Lanceolate cauline leaves present or absent \\
\hline C69 & & Ovate cauline leaves present or absent \\
\hline C70 & Leaves surface & Both surface has trichome or not \\
\hline C71 & & Glabrous above has trichome below \\
\hline $\mathrm{C} 72$ & Stipul existence & Present or absent \\
\hline $\mathrm{C} 73$ & Sepal center color & Purple or yellow \\
\hline C74 & Sepal margin color & White or yellow \\
\hline C75 & Sepal surface & Glabrous or not \\
\hline C76 & Petal color & White or yellow \\
\hline $\mathrm{C} 77$ & Stamen position & Equal or not \\
\hline C78 & Stamen number & 2 or not \\
\hline
\end{tabular}


Table 2. Continue

\begin{tabular}{lll}
\hline C79 & & 4 or not \\
\hline C80 & & 6 or not \\
\hline C81 & Pedicel position & Erect or not \\
\hline C82 & Pedicel surface & Glabrous or not \\
\hline C83 & Silicle shape & Ovate or not \\
\hline C84 & & Orbicular or not \\
\hline C85 & & Oblong or not \\
\hline C86 & Silicle wing existence & Present or absent \\
\hline C87 & Silicle surface & Glabrous or not \\
\hline C88 & Stilus position & Exceeding sinus or not \\
\hline C89 & Seed wing existence & Present or absent \\
\hline C90 & Seed shape & Ovate or not \\
\hline
\end{tabular}

two types of numerical analyses were performed using NTSYSpc 2.1 software (26). The first analysis was the Clustering Analysis (CA) and the second analysis was the Principle Components Analysis (PCA).

\section{RESULTS}

The result of the CA is the UPGMA (Unweighted Pair-Group Method using Arithmetic Averages) dendrogram (Figure 1).

The UPGMA dendrogram explains the numerical relationships of the taxa studied. According to the results; L. sativum ssp. sativum and $L$. sativum ssp. spinescens are the closest pair of taxa. $L$. spinosum is grouped with these two taxa and $L$. campestre is the closest species to the group. L. Iyratum and L. graminifolium are the second closest pair of taxa and related to L. latifolium. These taxa are grouped with $L$. ruderale and $L$. virginicum. The third closest pair of taxa are L. caespitosum and L. pumilum, which are grouped with L. cartilagineum.

PCA analysis results were coherent with the CA analysis (Figure 2). According to PCA analysis Lepidium sativum subsp. sativum and $L$. sativum subsp. spinescens the closest studied taxa and these taxa were grouped with $L$. campestre and L. spinosum. $L$. lyratum and $L$. graminifolium showed a close relation again and these taxa are grouped with L. ruderale, L. virginicum, L. Iatifolium like they were grouped in UPGMA dendrogram. L. caespitosum, L. pumilum and L. cartilagineum were also grouped. L. pumilum

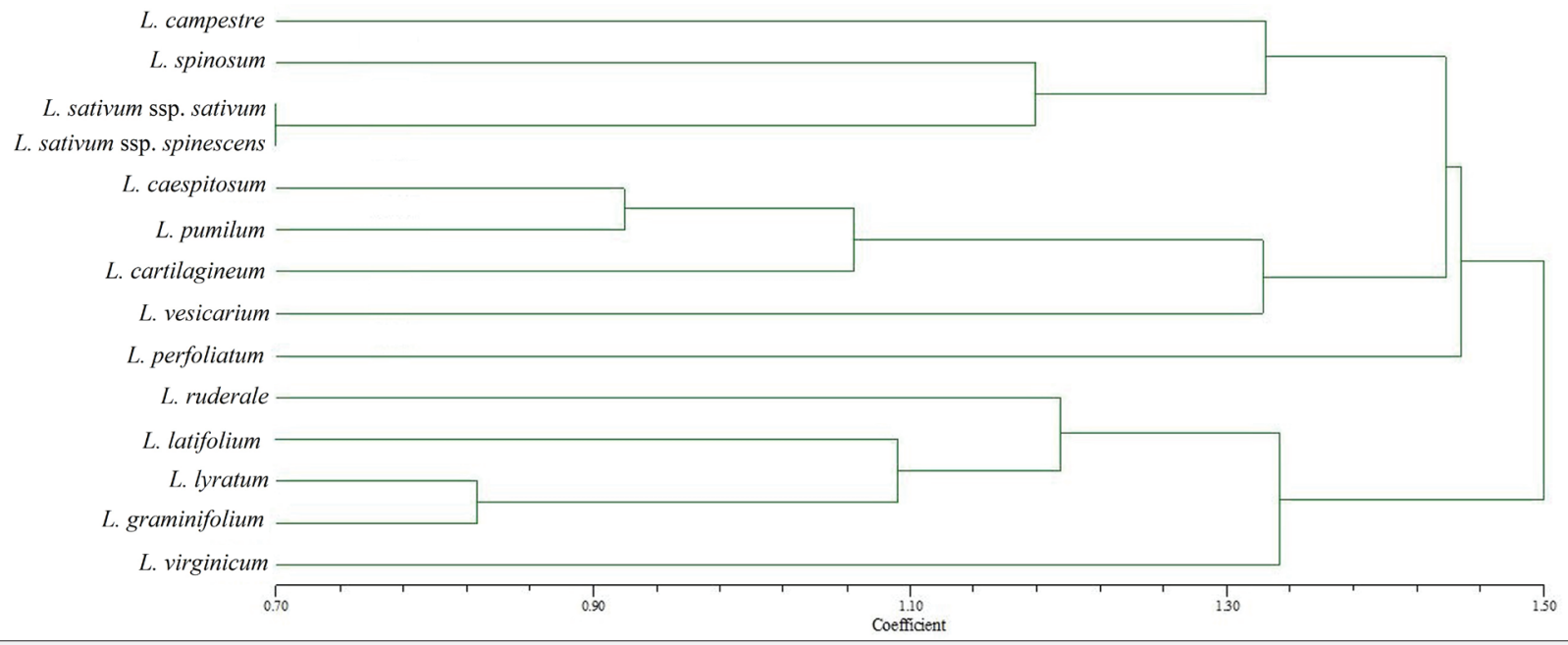

Figure 1. UPGMA Dendrogram. 


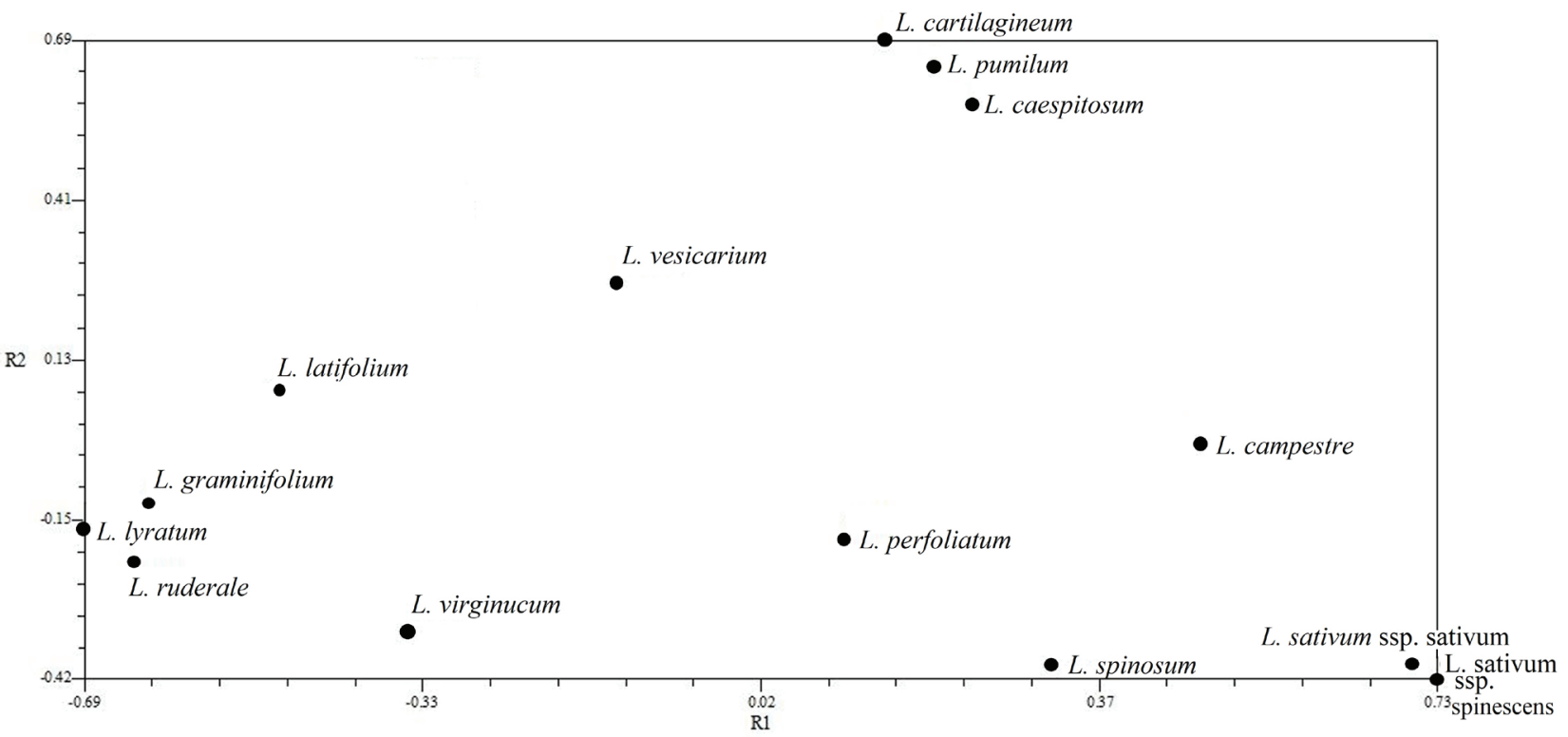

Figure 2. Position of studied taxa on the first two components.

has an equal distance from $L$. caespitosum and $L$. cartilagineum. The pictures of the studied taxa are given in Figures 3-5.

PCA analysis reduces numerous characters to a few number components. Table 3 shows the component's Eigen value and percentage of Eigen value. Eigen vector values of the first 4 components are given in Table 4. The first two components explain $39.61 \%$ of the total variation. According to the results of PCA analysis, the first five most effective characters describing the first component are seed length, the habitus of plant, the minimum and maximum length of sepal, and septum length. The first five most effective characters describing the second component are the seeds with or without wings, the presence of swelling leaf residues on the base of the plant, the length of the pedicel, the presence of the plant with a single stem, and the length of the septum.

\section{DISCUSSION}

L. spinosum, L. sativum ssp. sativum and L. sativum ssp. spinescens taxa (Figure 3) are clustered in this study and are placed in the section Lepiacardamon in classical systematic studies (7). According to the Flora of Turkey (7) L. campestre, the only taxon representing the section Lepia, is the closest species to the section Lepiocardamon (Figure 3). The dendrogram results are compatible with classical taxonomic data in this respect.

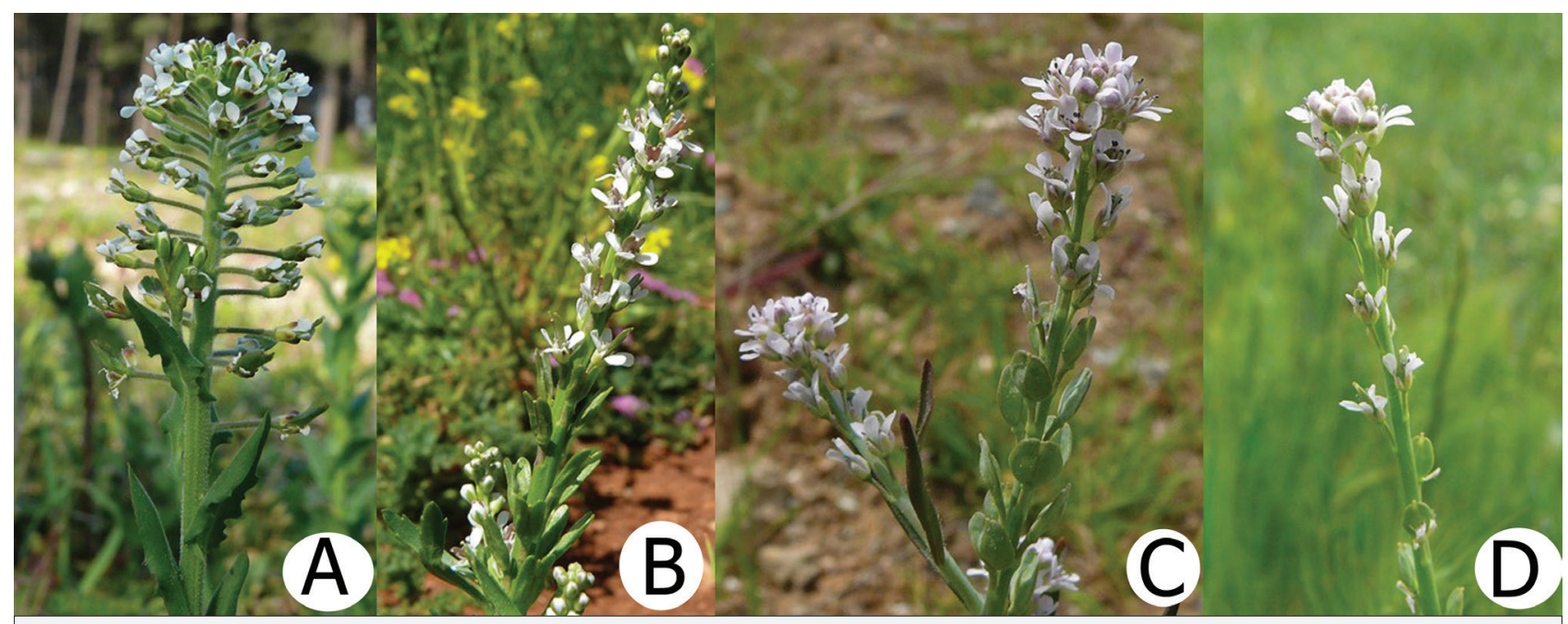

Figure 3. A) L. campestre, B) L. spinosum, C) L. sativum subsp. sativum, D) L. sativum subsp. spinescens. 


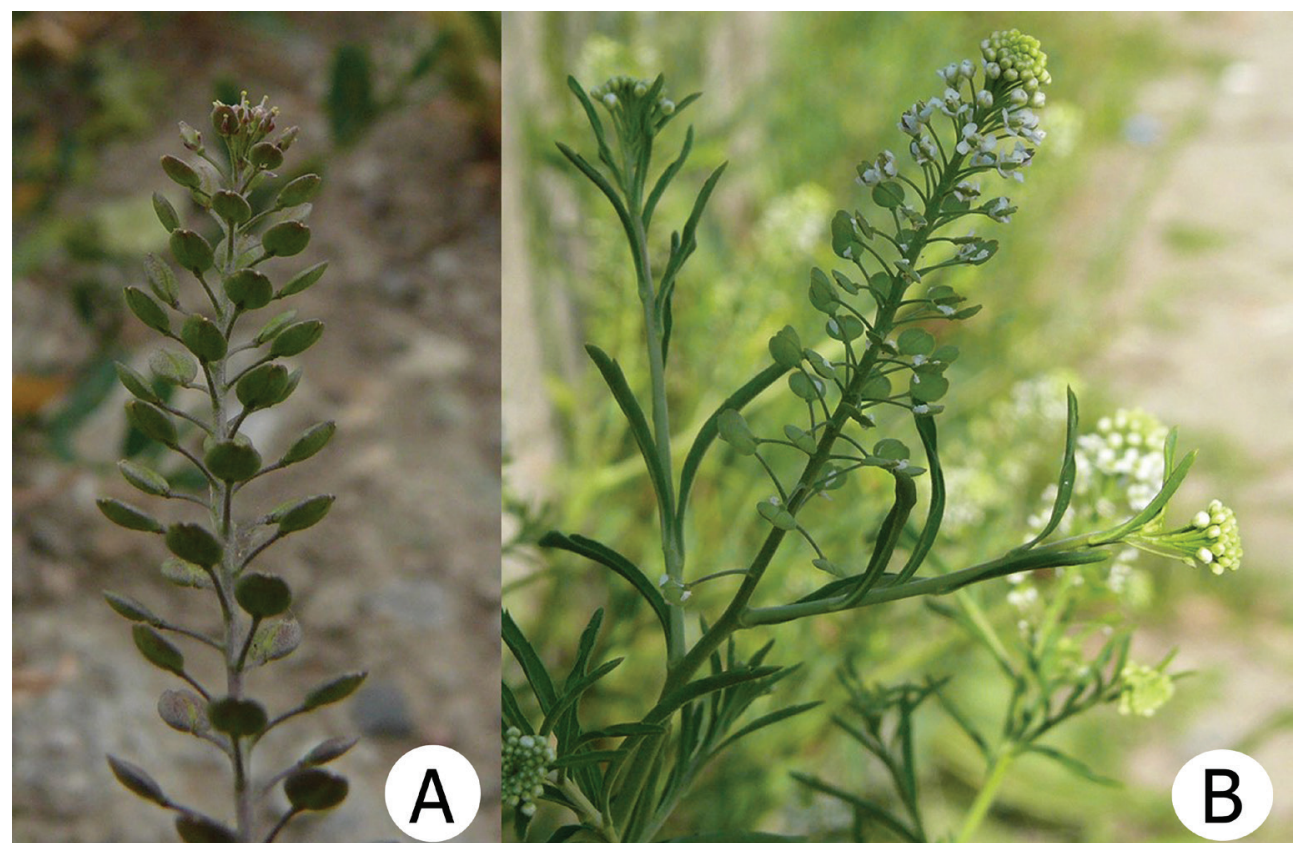

Figure 4. A) L. ruderale, B) L. virginicum.

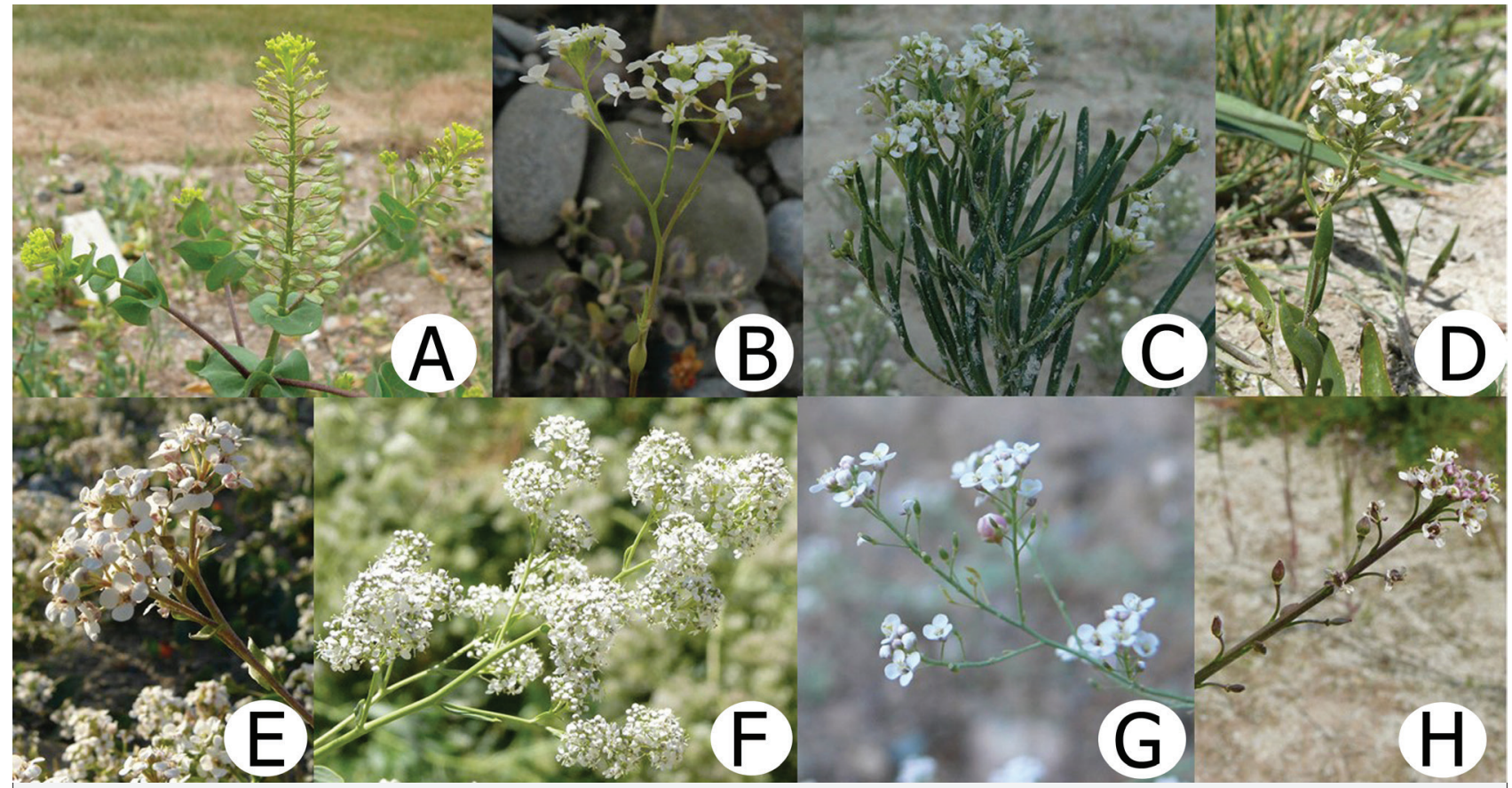

Figure 5. A) L. perfoliatum, B) L. vesicarium, C) L. caespitosum, D) L. pumilum, E) L. cartilagineum, F) L. Iatifolium, G) L. Iyratum, H) L. graminifolium.

L. sativum is grown as a cultivated plant in many parts of the world. Therefore, it is not easy to draw the boundaries of its geographical distribution. There are different taxonomic approaches in terms of intraspecific classification with the effect of this situation. The species has two subspecies according to the Flora of Turkey and Flora of Iraq $(7,27)$. In Flora of West Pakistan, the taxonomic level is defined as a variety, not a subspecies (28). According to the revision study conducted in Turkey, because of both the clarity of the morphological differences between the two taxa as well as due to differences in geographical dis- 
Eur J Biol 2020; 79(2): 132-143

Bona. Numerical Analysis of Turkish Lepidium s.s. taxa

Table 3. Eigen value and percentage of Eigen value of components.

\begin{tabular}{cccc}
\hline Components & Eigen Value & Percentage of Eigen Value & Total Percentage Eigen \\
\hline 1 & 21.6700 & 24.08 & 24.08 \\
\hline 2 & 13.9788 & 15.53 & 39.61 \\
\hline 3 & 10.8323 & 12.03 & 51.65 \\
\hline 4 & 8.3728 & 9.3 & 60.95 \\
\hline 5 & 6.4828 & 7.2 & 68.16 \\
\hline 6 & 5.7569 & 6.39 & 74.55 \\
\hline 7 & 4.9996 & 5.55 & 80.11 \\
\hline 8 & 4.4561 & 4.95 & 85.06 \\
\hline 9 & 4.1067 & 4.56 & 89.62 \\
\hline 10 & 3.7017 & 4.11 & 93.74 \\
\hline 11 & 2.5988 & 2.88 & 96.62 \\
\hline 12 & 1.7636 & 1.95 & 1.41 \\
\hline 13 & 1.2713 & 98.58 & 100 \\
\hline
\end{tabular}

Table 4. Component's Eigen vector value.

\begin{tabular}{|c|c|c|c|c|}
\hline & B1 & B2 & B3 & B4 \\
\hline $\mathrm{C} 1$ & 8.1577 & 1.7598 & 3.3445 & 7.6318 \\
\hline $\mathrm{C} 2$ & 7.8622 & -3.1628 & 6.4978 & -1.6688 \\
\hline $\mathrm{C} 3$ & 7.3615 & -5.525 & 7.1535 & -1.4991 \\
\hline $\mathrm{C} 4$ & 8.1577 & 1.7589 & 3.3443 & 7.6318 \\
\hline $\mathrm{C} 5$ & 7.4498 & -5.115 & -2.5845 & -1.7279 \\
\hline C6 & 7.4498 & -5.115 & -2.5845 & 1.7279 \\
\hline $\mathrm{C} 7$ & 8.1067 & 6.1259 & 2.8759 & -3.1068 \\
\hline $\mathrm{C} 8$ & 7.0984 & -1.7069 & 2.2081 & -3.9225 \\
\hline $\mathrm{C} 9$ & 7.2261 & -1.0386 & 2.8368 & 1.6263 \\
\hline C10 & 5.1939 & -4.874 & 1.1398 & -1.064 \\
\hline C11 & -1.3344 & 4.5014 & 4.2963 & -1.2953 \\
\hline C12 & 3.1741 & 7.5122 & 4.2598 & 9.0736 \\
\hline C13 & -6.4439 & 5.5676 & 3.7611 & -1.5546 \\
\hline C14 & 1.3431 & 8.4926 & -1.4174 & -9.391 \\
\hline C15 & 8.1577 & 1.7589 & 3.3443 & 7.6318 \\
\hline C16 & 8.2272 & -5.4576 & 9.4618 & -2.5207 \\
\hline $\mathrm{C} 17$ & 8.3823 & -7.2074 & 5.6088 & -1.4323 \\
\hline
\end{tabular}


Table 4. Continue.

\begin{tabular}{|c|c|c|c|c|}
\hline C18 & 7.009 & -3.8102 & -1.0506 & -3.4768 \\
\hline C19 & 7.528 & 4.4059 & 2.6295 & 2.6688 \\
\hline $\mathrm{C} 20$ & 2.801 & -1.0181 & 1.4588 & -5.5078 \\
\hline $\mathrm{C} 21$ & 7.528 & 4.4059 & 2.6295 & 2.6688 \\
\hline $\mathrm{C} 22$ & 7.0941 & 1.9486 & -6.6924 & -9.7554 \\
\hline $\mathrm{C} 23$ & 5.9917 & 5.0211 & -8.614 & 1.0578 \\
\hline $\mathrm{C} 24$ & 1.3428 & 3.1286 & -7.9831 & 3.6451 \\
\hline $\mathrm{C} 25$ & -1.408 & 5.7247 & 2.2524 & 3.4448 \\
\hline $\mathrm{C} 26$ & 1.051 & 2.7864 & -7.0197 & 7.8805 \\
\hline $\mathrm{C} 27$ & -3.313 & 2.5432 & 2.5923 & 5.3754 \\
\hline $\mathrm{C} 28$ & 8.5043 & 2.5371 & -2.1567 & -2.4258 \\
\hline $\mathrm{C} 29$ & 8.5043 & 2.5371 & -2.1567 & -2.4258 \\
\hline $\mathrm{C} 30$ & 5.5623 & 5.869 & -1.042 & -2.678 \\
\hline C31 & 1.3188 & 6.2204 & -4.0622 & -3.1672 \\
\hline $\mathrm{C} 32$ & 6.9054 & 4.0033 & -4.6847 & 3.6139 \\
\hline C33 & 3.789 & 2.8278 & -4.1131 & 5.3833 \\
\hline C34 & 1.4221 & 3.924 & -3.8543 & -1.9705 \\
\hline C35 & 1.6754 & 6.7856 & 3.7243 & -1.549 \\
\hline $\mathrm{C} 36$ & -3.2513 & 6.5742 & -1.7311 & 1.1972 \\
\hline C37 & 6.5701 & 2.4961 & -5.0581 & -2.4516 \\
\hline $\mathrm{C} 38$ & 4.3287 & 1.8748 & -4.5252 & 1.7334 \\
\hline C39 & 8.7965 & 2.9907 & 1.1786 & 1.425 \\
\hline $\mathrm{C} 40$ & 5.6454 & -4.5667 & 1.7145 & 3.261 \\
\hline C41 & 8.1577 & 1.7589 & 3.3443 & 7.6318 \\
\hline $\mathrm{C} 42$ & 7.009 & -3.8102 & -1.0506 & -3.4768 \\
\hline $\mathrm{C} 43$ & 8.1577 & 1.7589 & 3.3443 & 7.6318 \\
\hline $\mathrm{C} 44$ & 5.2255 & 2.7924 & 3.5573 & -2.0302 \\
\hline $\mathrm{C} 45$ & 4.4301 & -1.7607 & -5.6159 & -5.091 \\
\hline $\mathrm{C} 46$ & 3.8871 & -6.922 & -5.1692 & 3.2119 \\
\hline $\mathrm{C} 47$ & 3.5547 & -2.0308 & -3.6233 & -5.4515 \\
\hline $\mathrm{C} 48$ & -2.3959 & -4.1107 & -4.2069 & -7.7936 \\
\hline C49 & 4.0749 & -7.3958 & 4.1262 & -2.0175 \\
\hline $\mathrm{C} 50$ & 8.6528 & 5.0179 & 5.8839 & -1.687 \\
\hline C51 & -4.0749 & 7.3958 & -4.1262 & 2.0175 \\
\hline C52 & 4.7507 & -6.8027 & 1.9056 & 7.5579 \\
\hline
\end{tabular}


Table 4. Continue.

\begin{tabular}{|c|c|c|c|c|}
\hline C53 & -1.3428 & -3.1286 & 7.9831 & -3.6451 \\
\hline C54 & 2.3881 & 5.057 & 4.4158 & -4.327 \\
\hline C55 & -2.9336 & 4.3552 & 4.4765 & -5.122 \\
\hline C56 & 4.0356 & 1.1781 & 2.8518 & 6.6462 \\
\hline C57 & 2.1608 & 8.7231 & 2.1741 & -1.0536 \\
\hline C58 & 4.4758 & 2.8737 & 2.4905 & 1.7616 \\
\hline C59 & -3.9602 & 5.3022 & -3.3933 & -2.2854 \\
\hline $\mathrm{C} 60$ & -1.2301 & 3.7383 & -2.8989 & -4.2022 \\
\hline C61 & 1.0647 & -4.7006 & -4.6956 & -5.4175 \\
\hline C62 & 2.8898 & -5.7685 & 5.0445 & 1.737 \\
\hline C63 & -4.8731 & -3.4476 & 1.8812 & 5.6061 \\
\hline C64 & -1.1663 & -4.6782 & 1.5965 & -4.2597 \\
\hline $\mathrm{C} 65$ & -1.4111 & -4.2019 & 8.2345 & 4.1765 \\
\hline $\mathrm{C} 66$ & -4.7657 & 2.5251 & 1.6425 & -7.5776 \\
\hline C67 & 7.7308 & -1.9457 & -5.1567 & -7.1191 \\
\hline C68 & -1.6978 & -1.2835 & 3.7654 & 5.2953 \\
\hline C69 & -1.0993 & -2.7311 & -4.7492 & 1.0636 \\
\hline $\mathrm{C} 70$ & 2.547 & 4.2819 & -2.3125 & 4.7474 \\
\hline C71 & -4.7657 & 2.5251 & 1.6425 & -7.5776 \\
\hline $\mathrm{C} 72$ & -2.6955 & -2.2652 & -4.9657 & 4.3641 \\
\hline $\mathrm{C} 73$ & -2.0825 & -3.9243 & 3.083 & 4.2735 \\
\hline $\mathrm{C} 74$ & 6.2841 & -1.307 & 5.8645 & 2.4181 \\
\hline $\mathrm{C} 75$ & 2.1569 & -2.6125 & 2.4595 & 1.6409 \\
\hline $\mathrm{C} 76$ & -2.2815 & -2.1394 & 6.5289 & 3.1386 \\
\hline $\mathrm{C} 77$ & 2.8233 & 2.3518 & -1.0312 & 6.119 \\
\hline $\mathrm{C} 78$ & 4.2576 & 3.0021 & -4.9163 & 8.3012 \\
\hline C79 & 2.0464 & 2.4789 & -3.6733 & 1.3125 \\
\hline $\mathrm{C} 80$ & -4.2576 & -3.0021 & 4.9163 & -8.3012 \\
\hline $\mathrm{C} 81$ & -6.4439 & 5.5676 & 3.7611 & -1.5546 \\
\hline $\mathrm{C} 82$ & -1.6183 & 6.0073 & 4.6361 & -6.1571 \\
\hline C83 & -2.3005 & -3.2699 & -3.0227 & -5.9666 \\
\hline $\mathrm{C} 84$ & 3.4683 & 3.9177 & 6.5477 & 2.8762 \\
\hline C85 & -3.4604 & 2.2105 & 1.0309 & 5.8767 \\
\hline $\mathrm{C} 86$ & -5.097 & -4.4255 & -5.8116 & -1.3273 \\
\hline $\mathrm{C} 87$ & -7.2798 & -1.711 & -5.8173 & -3.1014 \\
\hline $\mathrm{C} 88$ & 2.4089 & -6.9602 & 3.6955 & 7.2506 \\
\hline C89 & -5.0479 & -9.7737 & 6.1954 & 1.0801 \\
\hline $\mathrm{C} 90$ & -5.9977 & -1.4795 & 2.0557 & 3.4321 \\
\hline
\end{tabular}


tribution seen between populations, it is stated that the definition should be at the subspecies level. In the Turkey Plant List (Vascular Plants), both subspecies and varieties are listed as a synonym and $L$. sativum is shown as a single species (22). The results of this study support the view that the $L$. sativum species should be better evaluated as two subspecies.

L. latifolium, L. lyratum, and L. graminifolium (Figure 4) are placed together in section Lepidium (7). These species also formed a group in this study and numerical results support the sectional classification. L. ruderale and L. virginicum (Figure 5), the closest species to the group according to the numerical analysis, are also placed in section Dileptum in the Flora of Turkey $(7,9)$.

The last group comprises $L$. caespitosum, $L$. pumilum and $L$. crassifolium. L. caespitosum (Figure 5) was evaluated as an endemic species in the Flora of Turkey (7). According to Flora of Turkey (7), L. pumilum and L. crassifolium were represented as two subspecies; L. cartilagineum (J. May.) Thell. subsp. cartilagineum and L. cartilagineum (J. May.) Thell. ssp. crassifolium (Waldst. \& Kit.) Thell. Later, Hedge (29) again accepted them as two subspecies but with a new combination. In the Flora of the USSR, they are accepted as separate species (30). These three taxa were listed as subspecies of $L$. cartilagineum by Mutlu (22) while the revision of Turkish Lepidium proposed they must be considered as different species (24). Numerical analysis results in this study support the idea of evaluating these three taxa as separate species. It also shows that $L$. pumilum is closer to $L$. caespitosum than to $L$. cartilagineum.

There is a tendency for some of the flower parts to be reduced to the point of absence, and hence flower structure is used in the subgeneric classification in the genus Lepidium (31). Flower structure and the characters of vegetative morphology are used in species identification in the genus Lepidium $(32,33)$. The results of PCA analysis support the idea that the habitus of plant, the minimum and maximum length of sepal, the presence of swelling leaf residues on the base of the plant, and the presence of the plant with a single stem are important characters.

It has been reported that seed characters tend to have been ignored in Lepidium, with the exception of trifid cotyledon of L. sativum $(31,33)$. However, the results of the present study showed that seed length, septum length, and the eventual presence and features of the seed wing are diagnostic characteristics for the genus Lepidium. This result is coherent with studies using seed characteristics for taxonomic studies in Lepidium $(31,34,35)$.

Numerical analysis of L. sativum based on 21 morphological traits was performed based on Iranian specimens (36). According to that analysis, the first principal component analysis explained $63.0 \%$ of the total variation present in the dataset, besides that, petal length and sepal length and width had the highest positive correlation in PCA analysis (36). The present PCA analysis also shows that the sepal and petal length are two important characteristics that explain the first two components.

\section{CONCLUSION}

Numerical analysis studies based on morphological data on Lepidium taxa growing in Turkey is a useful tool for solving the taxonomic problems of taxa belonging to the genus Lepidium. This study gave significant results as the first step towards more comprehensive studies including more taxa.

\section{Proposed Treatment for Turkish Lepidium L. taxa}

Section Lepia (Desv.) DC.

L. campestre (L.) Aiton, Hort. Kew. ed. 2, 4: 88 (1812).

Section Lepiocardamon Thell.

L. spinosum Ard., Animad. Specim. Alt. 2: 34, t. 16 (1764).

L. sativum L., Sp. PI. 2: 644 (1753). subsp. sativum

L. sativum L. subsp. spinescens (DC.) Thell. in Vierteljahr. Naturf. Ges. Zürich, 51: 161 (1906)

Section Dileptium DC.

L. ruderale L., Sp. PI. 2: 645 (1753).

L. virginicum L., Sp. PI. 2: 645 (1753)

Section Lepidium

L. perfoliatum L., Sp. PI. 2: 643 (1753)

L. vesicarium L., Sp. PI. 2: 643 (1753)

L. caespitosum Desv. in J. Bot. Agric. 3: 165 \& 178 (1815)

L. pumilum Boiss. \& Bal. in Boiss., Diagn. ser. 2(6): 21 (1859)

L. cartilagineum (J. May.) Thell. in Vierteljahr. Naturf. Ges. Zürich

51: 173 (1906)

L. Iatifolium L., Sp. PI. 2: 644 (1753)

L. lyratum L., Sp. PI. 2: 644 (1753).

L. graminifolium L., Syst. Nat. ed. 10, 2: 1127 (1759)

Peer-review: Externally peer-reviewed.

Authors Contributions: Concept: M.B.; Design: M.B.; Supervision: M.B.; Materials: M.B.; Data Collection and/or Processing: M.B.; Analysis and/or Interpretation: M.B.; Literature Search: M.B.; Writing: M.B.; Critical Reviews: M.B.

Conflict of Interest: The authors declare that they have no conflicts of interest to disclose.

Financial Disclosure: There are no funders to report for this submission.

\section{REFERENCES}

1. Koch MA, Mummenhoff K. Editorial: Evolution and phylogeny of the Brassicaceae. Plant Syst Evol 2006; 259: 81-3.

2. Roughani A, Miri SM, Hassandokht MR, Moradi P, Abdossi V. Genetic variation within Iranian Lepidium species using morphological traits. The First National Congress and International Fair of Medicinal Plants and Strategies for Persian Medicine that Affect Diabetes. 2018 Oct 9; Mashhad, Iran; 2018.

3. Al-Shehbaz IA. A generic and tribal synopsis of the Brassicaceae (Cruciferae). Taxon 2012; 61: 931-54.

4. Khalik KA, van der Maesen LJG, Koopman WJM, van den Berg RG. Numerical taxonomic study of some tribes of Brassicaceae from Egypt. Plant Syst Evol 2002; 233: 147-275.

5. De Candolle P. Regni Vegetabilis Systema Naturale, Volume 2. Paris: Sumptibus Sociorum Treuttel et Würtz; 1821. 
6. Schulz OE. Cruciferae. Engler A, Harms H, editors. Die Naturlichen Pflanzenfamilien ed. 2, 17B. Leipzig: Verlag von Wilhelm Engelmann; 1936. p. 227-658.

7. Hedge, IC. Lepidium L. Davis PH, editor. Flora of Turkey and the East Aegean Islands Volume I. Edinburgh: Edinburgh University Press; 1965. p. 279-285.

8. Davis PH, Mill RR, Tan K. Flora of Turkey and the East Eagean Islands Volume X. Edinburgh: Edinburgh University Press; 1988.

9. Güner A, Özhatay N, Ekim T, Başer KHC. Cruciferae. Flora of Turkey and the East Aegean Island Volume XI. Edinburgh: Edinburgh University Press; 2000.

10. Koch M, Al-Shehbaz IA, Mummenhoff K. Molecular Systematics, Evolution, and Population Biology in The Mustard Family (Brassicaceae). Ann Mo Bot Gard 2003; 90: 151-71.

11. Beilstein MA, Al-Shehbaz IA, Kellogg EA. Brassicaceae phylogeny and trichome evolution. Am J Bot 2006; 93: 607-19.

12. Al-Shehbaz IA, Beilstein MA, Kellogg EA. Systematics and phylogeny of the Brassicaceae (Cruciferae): an overview. Plant Syst Evol 2006; 259: 89-120.

13. Al-Shehbaz IA, Mutlu B, Dönmez AA. The Brassiceae (Cruciferae) of Turkey, updated. Turk J Botany 2007; 31: 327-36.

14. Al-Shehbaz IA. The genera of Lepidieae (Cruciferae; Brassicaceae) in the southeastern United States. J Arnold Arbor 1986; 67: 265-311.

15. Thellung A. Die Gattung Lepidium (L.) R. Br. Zürih:Verlag von Georg \& Co. 1906.

16. Mulligan GA, Frankton C. Taxonomy of the genus Cardaria with particular reference to the species introduced into North America. Can J Bot 1962; 4: 1411-25.

17. Mummenhoff K. Should Cardaria draba (L.) DESV. be classified within the genus Lepidium L. (Brassicaceae) Evidence from subunit polypeptide composition of RUBISCO. Feddes Repert 1995; 106: 25-8.

18. Al-Shehbaz IA, Mummenhoff K, Appel O. Cardaria, Coronopus, and Stroganowia are united with Lepidium (Brassicaceae). Novon 2002; 12: 5-11.

19. Bailey CD, Koch MA, Mayer M, Mummenhoff K, O'Kane SL, Warwick $\mathrm{SI}$, Windham MD, Al-Shehbaz IA. Towards a global nrDNA ITS phylogeny of the Brassicaceae. Mol Biol Evol 2006; 23: 2142-60.

20. Al-Shehbaz IA, Mummenhoff K. Stubendorffia and Winklera belong to the expanded Lepidium (Brassicaceae). Edinb J Bot 2011; 68: 165-70.
21. Dorofeyev VI, Korotyaev BA, Gültekin L. A new species of the genus Stroganowia Kar. et Kir. (Cruciferae) from Northeast Turkey and Rhynchophorous beetles (Coleoptera, Curculionoidea) associated with it. Byull Moskovsk Obshch Isp Prir Otd Biol 2004; 109: 72-6.

22. Mutlu B. Lepidium L. Güner A, Aslan S, Ekim T, Vural M, Babaç MT, editors. Türkiye Bitkileri Listesi (Damarlı Bitkiler). İstanbul: Nezahat Gökyiğit Botanik Bahçesi ve Flora Araştırmaları Derneği Yayını; 2012. p. 284-287.

23. Yüzbaşıoğlu is, Keskin M. A new record for the flora of Turkey: Lepidium didymum L. (Brassicaceae). Biodicon 2013; 6: 46-8.

24. Bona M. Taxonomic revision of Lepidium L. (Brassicaceae) from Turkey. J Fac Pharm Ist Univ 2014; 44: 31-62.

25. Sokal RR, Sneath PHA. Principles of Numerical Taxonomy. USA: W.H. Freeman and Company; 1963.

26. Rohlf FJ. NTSYSpc Numerical Taxonomy and Multivariate Analysis System User Guide. New York: Exeter Software; 1998.

27. Hedge IC, Lamond JM. Brassicaceae. Townsend CC, Guest E, editors. Flora of Iraq Volume IV. Baghdad: Ministry of Agriculture; 1980. p. 827-1199.

28. Jafri SMH. Flora of West Pakistan No: 55 Brassicaceae. Karachi University of Karachi; 1973.

29. Hedge IC. Lepidium L. Rechinger KH, editor. Flora Iranica. 57/28. 2, Graz: Akademische Druck- und Verlag-Anst; 1968. p. 63-72.

30. Juss B. Lepidium L. Komarov VL. Flora of the USSR Volume VIII, Jerusalem: Israel Program for Scientific Translations Ltd.; 1939.

31. Hewson HJ. The genus Lepidium L. (Brassicaceae) in Australia. Brunonia 1981; 4: 217-308.

32. Bona M. Distribution of Lepidium taxa in Turkey. Bocconea 2012; 24: 221-5.

33. Nasseh $Y$, Joharchi MR. A new record of Lepidium (Brassicaceae) for the flora of Iran. Nova Biologica Reperta. 2019; 6: 347-51.

34. Bona M. Seed-coat microsculpturing of Turkish Lepidium (Brassicaceae) and its systematic application. Turk J Botany 2013; 37: 662-8.

35. Song JH, Moon BC, Choi G, Yang S. Morphological identification of Lepidii Seu Descurainiae Semen and adulterant seeds using microscopic analysis. Applied Sciences 2018; 8: 2134.

36. Roughani A, Miri SM, Hassandokht MR, Moradi P, Abdossi V. Agro-morphological study on several accessions of garden cress (Lepidium sativum-Brassiaceae) in Iran. Pak J Bot 2018; 50: 655-60. 